\title{
Impacts of climate change on Chinese ecosystems: key vulnerable regions and potential thresholds
}

\author{
Jian Ni
}

Accepted: 15 October 2010/Published online: 13 November 2010

(C) Springer-Verlag 2010

\begin{abstract}
China is a key vulnerable region of climate change in the world. Climate warming and general increase in precipitation with strong temporal and spatial variations have happened in China during the past century. Such changes in climate associated with the human disturbances have influenced natural ecosystems of China, leading to the advanced plant phenology in spring, lengthened growing season of vegetation, modified composition and geographical pattern of vegetation, especially in ecotone and tree-lines, and the increases in vegetation cover, vegetation activity and net primary productivity. Increases in temperature, changes in precipitation regime and $\mathrm{CO}_{2}$ concentration enrichment will happen in the future in China according to climate model simulations. The projected climate scenarios (associated with land use changes again) will significantly influence Chinese ecosystems, resulting in a northward shift of all forests, disappearance of boreal forest from northeastern China, new tropical forests and woodlands move into the tropics, an eastward shift of grasslands (expansion) and deserts (shrinkage), a reduction in alpine vegetation and an increase in net primary productivity of most vegetation types. Ecosystems in northern and western parts of China are more vulnerable to climate changes than those in eastern China, while ecosystems in the east are more vulnerable to land use changes other than climate changes. Such assessment could be helpful to
\end{abstract}

J. Ni

State Key Laboratory of Vegetation and Environmental Change, Institute of Botany, Chinese Academy of Sciences,

Xiangshan Nanxincun 20, 100093 Beijing, China

J. Ni ( $($ )

Alfred Wegener Institute for Polar and Marine Research,

Telegrafenberg A43, 14473 Potsdam, Germany

e-mail: jni@awi.de address the ultimate objective of the United Nations Framework Convention on Climate Change (UNFCCC Article 2).

Keywords Human disturbance - Net primary production . Species distribution - Vegetation model $\cdot$ Vegetation shift

\section{Introduction}

Global change, including the changes in atmospheric composition, climate and land use, has modified and will affect the climate system, natural and anthropogenic-influenced ecosystems, as well as socio-economic development. These changes have the potential to impact food production, human health and sustainable development of people around the world. Anthropogenic climate change is an important and major component of global change. It includes many issues such as the intensity and frequency of extreme events, the magnitude and rate of change, the change of mean climate state and climate variability, longterm and short-term changes, and rapid or abrupt changes. Together, these changes will eventually affect the physical, biological, social and economic systems of the world, including impacts on ecosystems, food production and sustainable development. However, uncertainty remains about the specific responses of the natural system, including the atmosphere, hydrosphere, biosphere, geosphere, their interactions and the socio-economic system, to the impacts of climate change and which feedbacks to climate change might occur. What is the vulnerability and adaptive capacity of these systems? Research to address these questions is required in order to achieve the ultimate objective of the United Nations Framework Convention on Climate Change (UNFCCC) Article 2, calling to avoid, “...dangerous 
anthropogenic interference with the climate system ... within a time frame sufficient to allow ecosystems to adapt naturally to climate change, to ensure that food production is not threatened and to enable economic development to proceed in a sustainable manner" (UNFCCC 1992).

China is a vast territory with varied topography and climate regimes, diverse ecosystems, as well as high population pressure and long-term human disturbances. The country encompasses various climate regimes from northern boreal to southern tropical and from western arid to eastern and southern humid climate zones. The dynamics of the East Asian summer and winter monsoons, and the huge uplift of the Tibetan Plateau, contribute to producing a highly diverse set of ecosystems including boreal coniferous forest, temperate deciduous forest, subtropical evergreen broadleaved forest, tropical rainforest and seasonal forest from north to south in the east part, and temperate steppe and deserts from east to west in the northern part, as well as tundra and alpine steppe and desert on the Tibetan Plateau. A long history of social development and agricultural cultivation as well as high population pressure has strongly disturbed the natural ecosystems. Climate change and variability associated with the acceleration of human disturbance have already affected these ecosystems, food production and sustainable development of China (Piao et al. 2010). The projected climate scenarios could have significant impacts on both natural and socio-economic systems in future.

In order to effectively implement the UNFCCC, we need to address the projected effects of climate change on ecosystems and species and in particular to identify the impacts at different time periods in the future at different levels of climate change (e.g., Schröter et al. 2005; Scholze et al. 2006). This paper synthesizes the historical and recent climate changes of the past century and their impacts on Chinese natural ecosystems. The projected impacts of climate change on Chinese ecosystems in the future 50-100 years at the national level and in some key vulnerable regions are then evaluated.

\section{Observed changes}

China has 23 provinces, 5 autonomous regions, 4 municipalities and 2 special administrative regions (Fig. 1a). Roughly, it can be divided into eight large geographical regions (Fig. 1b): Northeast (Heilongjiang, Jilin, Liaoning, northern Inner Mongolia), North (Beijing, Tianjin, Hebei, Shanxi, Shaanxi, middle to western Inner Mongolia, Ningxia, middle to eastern Gansu), Northwest (Xinjiang, western Gansu, northern Qinghai), East (Shandong, Jiangsu, Anhui, Shanghai, Zhejiang, Fujian, Taiwan), Central (Henan, Jiangxi, Hubei, Hunan), South (Guangdong, Guangxi, Hainan, Hongkong, Macau), Southwest (middle to eastern Sichuan, Chongqing, Guizhou, Yunnan) and the Tibet (Xizang, southern Qinghai, eastern Sichuan).

Climate and hydrology

\section{Temperature, precipitation and drought}

On average, the twentieth century was $0.4^{\circ} \mathrm{C}$ warmer than the last millennium, and it was likely the warmest period in the past 1,000 years in China (Wang and Gong 2000; Wang et al. 2001). Instrumental records show an increase in mean and extreme temperatures during the past century, especially during the 1980-2000 (Shen and Varis 2001; Wang and Gaffen 2001; Yan et al. 2002; Zhai and Pan 2003; Gong et al. 2004a; Qian and Lin 2004; Liu et al. 2006). Changes in precipitation and extreme events show more complex patterns (increases or decreases) in time and space (Gong and Wang 2000; Wang and Gaffen 2001; Liu et al. 2005a; Wang and Zhou 2005; Qian et al. 2007; Qian and Qin 2008; Zhang et al. 2009), but a general increase by $2 \%$ was found since 1960 , with a $10 \%$ decrease in the frequency of precipitation events (Liu et al. 2005a). Drought does not show any trend across the country since the 1950s; however, a significant increase in drought-affected areas was found in northern China (Zou et al. 2005). Observations also indicate a decrease in pan evaporation with regional differences (Liu
Fig. 1 China: a location of provinces, autonomous regions, municipalities and special administrative regions, b geographical division
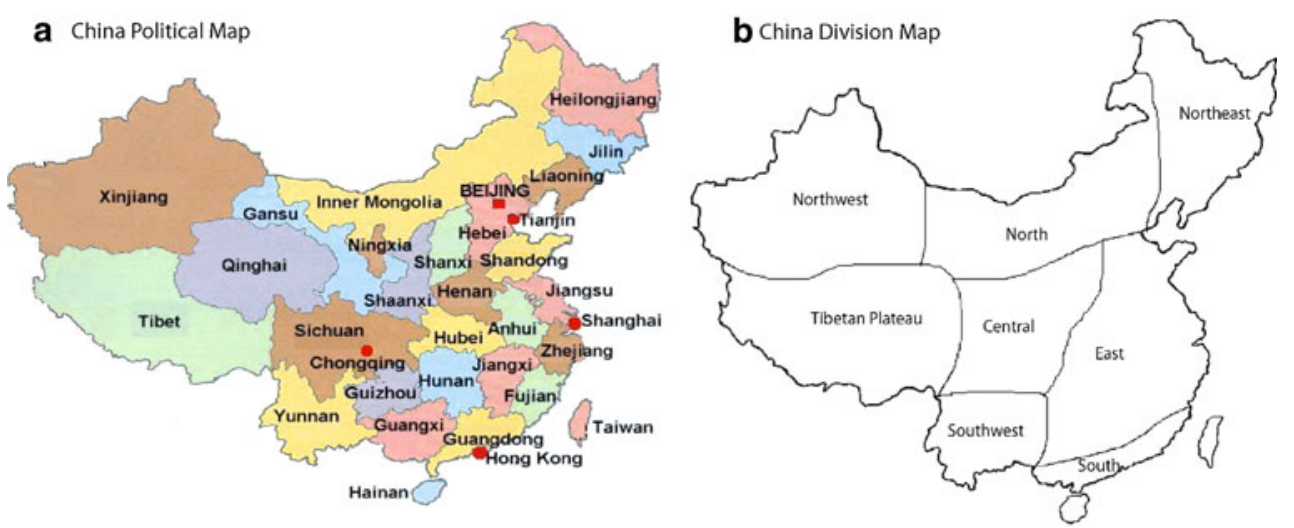
et al. 2004; Zhang et al. 2007) along with a significant decrease in solar radiation (Che et al. 2005). Estimated actual evapotranspiration during 1960-2002 decreased in eastern China $\left(>100^{\circ} \mathrm{E}\right)$ and increased in western China (Gao et al. 2007). Temperature, precipitation and drought in China vary strongly, both seasonally and regionally (Qian and Zhu 2001; Hu et al. 2003; Du et al. 2004; Gemmer et al. 2004; Qian and Lin 2004; Gong et al. 2004b; Zhao et al. 2004; Liu et al. 2005a; Wang and Zhou 2005; Zou et al. 2005; Shi et al. 2007; Qian and Qin 2008; Zhang et al. 2009). Despite the changes in the period of climate observations and the number of weather stations used by different researchers, the trends of observed climate change are very similar. It can therefore be concluded that the climatic regime has shifted in China during the past century (Qian et al. 2007; Qian and Qin 2008).

\section{Snow, glacier and water resources}

Over the Tibetan Plateau, snow depth has sharply increased since the late 1970s, accompanied by more precipitation and land surface cooling (Zhang et al. 2004). Northwestern China also shows increases in snow mass and durations since 1987 (Li 1999). Most of the glaciers in southwestern and northwestern China and on the Tibetan Plateau have retreated to some extent during the last 400 years (Shi and Liu 2000; Su and Shi 2002; He et al. 2003; Shi et al. 2007). Retreat rates accelerated after the 1950-1980 (He et al. 2003; Liu et al. 2003). As a consequence, spring run-off for most rivers in northwestern China increased after the 1980s (Liu et al. 1999; Shi et al. 2007). On the other hand, since the early twentieth century, significant permafrost degradation occurred in most permafrost regions in China (Jin et al. 2000), especially on the inland and northern Tibetan Plateau (Zhao et al. 2004). The frost period also decreased by 10 days over many northern regions of China (Schwartz and Chen 2002).

The water resources of China under climate change conditions are a major concern in the arid and semi-arid regions and in some large river basins such as the Yellow River and the Yangtze River. The surface water resource in the arid zone of northwestern China decreased during the twentieth century due to the warmer and drier climates (Shi and Zhang 1995). After consideration of changes in human use, run-off of the Yellow River basin has decreased (Fu et al. 2004; Liu and Zheng 2004; Yang et al. 2004b). In particular, the main stream of the river along the lower reach has dried up since 1972, and the situation has become critical since the 1990s (Yang et al. 2004a).

\section{Coast and sea level}

Chinese coastal regions are high risk areas for natural disasters due to their low-lying character and sensitive environments. The rate of sea-level rise during the past 100 years was $2-3 \mathrm{~mm}$ year $^{-1}$ (Ren 1993; Cui and Zorita 1998; Li et al. 2002).

Natural ecosystems

\section{Phenology}

Growing season length in China has increased during the past two decades (Fang et al. 2004; Piao et al. 2005c). In the temperate zone of China, the growing season duration has lengthened by 1.16 days per year between 1982 and 1999, with spring occurring 0.79 days earlier and autumn arriving 0.37 days later. This is mostly related to increasing summer temperature; however, precipitation changes have affected vegetation types and phenological phases differently (Piao et al. 2006). Plant phenology data from 26 stations show that the plant phenophase had either advanced or been delayed during the past 40 years. Phenophases have advanced in northeastern China, northern China and the lower reaches of the Yangtze River and have been delayed in the eastern part of southwestern China and the middle reaches of the Yangtze River. Such changes have nonlinear relationships with temperature change and vary in different geographical regions (Zheng et al. 2002). In eastern China, phenological and meteorological data from 1982 to 1993 at three weather stations also show that an average mean air temperature increase by $1{ }^{\circ} \mathrm{C}$ in late winter and spring advances the onset of the growing season by 5-6 days while ending it 5 days later. Moreover, if autumn precipitation increases by $100 \mathrm{~mm}$, then the end of the growing season would advance by 6- 8 days (Chen and Pan 2002). A further analysis at seven stations with normalized difference vegetation index (NDVI) data shows that the growing season has, on average, increased by 1.4-3.6 days per year in the northern zones and by 1.4 days per year across eastern China on average (Chen et al. 2005). In urban environments such as in Beijing, the urban heat island effect is the dominant cause of observed phenological change (Luo et al. 2007).

\section{Vegetation structure and pattern}

Changes in potential vegetation change in China since about 1950 have been estimated using the Holdridge life zone approach (Yue et al. 2005, 2001), but satellite data (NDVI) indicate the changes in actual ecosystems. The variations of NDVI from 1982 to 1999 show that vegetation greening and expansion increased during the past 18 years in almost all regions in China (Piao et al. 2003a, 2004; Fang et al. 2004). Compared to the early 1980s, vegetated area (NDVI $>0.1$ ) increased by $3.5 \%$ by the late 1990 s, while sparsely vegetated area $(\mathrm{NDVI}<0.1)$ 
declined by $18.1 \%$ during the same period. The national mean annual NDVI increased by $7.4 \%$ due to the increase in growing season duration and increased plant growth rates as well as increases in temperature and summer rainfall, and increase in agricultural area (Fang et al. 2004). However, NDVI changes in China were spatially heterogenous; the eastern coastal regions showed declines or small increase, while the agricultural regions and western China experienced marked increases (Fang et al. 2004; Piao et al. 2003a, 2004). For example, agricultural practices caused an increase in NDVI in the North China Plain, and rapid urbanization in the Yangtze River and Pearl River Deltas resulted in a sharp decrease in NDVI since the 1980s (Piao et al. 2003b, 2004).

Regional studies also demonstrated changes in vegetation and species during the past decades. A previous study based on satellite imagery between 1972 and 1988 in the Changbai Mountain Reserve in northeastern China showed that forests covered $84.4 \%$ of the study area in 1972 and $74.5 \%$ in 1988. Landscape patterns in 1988 were more complex, more irregular and more fragmented than in 1972 (Zheng et al. 1997). The digitized maps of five forest landscapes in northeastern China show that from 1896 to 1986, the total areas of coniferous forests (Picea abies forest, Pinus sylvestris var. mongolica forest and Pinus koraiensis forest) decreased about $40-87 \%$, and of broadleaved forest increased about $500 \%$ with its northern limit moved toward northwest about $290 \mathrm{~km}$ (Chen 2000). Plotbased information from the southern part of northeast China indicates that between 1986 and 1994, the relative abundance of different tree species changed (Chen et al. 2000, 2003c; Chen 2001). Pinus koraiensis and Fraxinus rhynchophylla spread toward the west and the east, respectively. Areas of Pinus koraiensis, Populus davidiana, Phellodendron amurense, Juglans mandshurica, Fraxinus mandshurica, Betula dahurica, Picea koraiensis, Abies nephrolepis and Larix olgensis var. koreana decreased, while Quercus mongolica, Betula costata, Acer mono, Tilia spp., Ulmus spp., Betula platyphylla and Fraxinus rhynchophylla increased (Chen 2000, 2001; Chen and $\mathrm{Li}$ 2003). In general, such changes are attributed to regional climate change, but anthropogenic disturbance such as logging has also contributed.

The arid and semiarid areas in northern and western China experienced dramatic changes in vegetation pattern during the past 50 years, due to their greater sensitivity to climate change and human disturbance compared to other areas of China. NDVI data show a decline in desertification in the past two decades due to a change from warm and arid to warm and wet climate with less disturbance from human activities (Piao et al. 2005b). Life zone diversity in Xinjiang of northwestern China was the highest in the 1960s, dramatically decreased in the 1970s, and then gradually increased in the 1980s and 1990s, implying a more stable environment since the 1970s (Zheng et al. 2006a). However, statistical assessments indicate increasing desertification in some regions (Chen and Tang 2005; Yang et al. 2005). Climate change has a strong effect, but human activities such as overgrazing, land use change and population pressure in semiarid China contribute to increasing this desertification trend ( $\mathrm{Li}$ et al. 2000; Chen and Tang 2005; Yang et al. 2005; Wang et al. 2006; Zheng et al. 2006b).

\section{Net primary production}

China's terrestrial net primary production (NPP) increased by $18.7-24.2 \%$ from 1982 to 1999 (Fang et al. 2003; Piao et al. 2005b; Zhu et al. 2007), along with significant upward trends in growing season leaf area index (LAI) and vegetation greening (Piao et al. 2004; Xiao and Moody 2004). Seasonal total NPP in China significantly increased in all four seasons during the past 18 years, with the largest increase rate in spring and the greatest magnitude of increase in summer (Piao et al. 2003b). A great deal of spatial heterogeneity exist in historical NPP trends, with a significant increase of over $30.8 \%$ of China and a decrease in areas undergoing rapid urbanization (Fang et al. 2003; Piao et al. 2005a). The increased NPP is primarily due to the increases in crop yields, forest plantation and growing season length for some evergreen and deciduous forests in eastern China, as well as increasing vegetation activity (Fang et al. 2004; Piao et al. 2005a). Such response of NPP to climate change is related to different vegetation types and depends on regional climate attributes and their changes such as the major ENSO and monsoon dynamics (Piao et al. 2003a, 2005b; Fang et al. 2005; Zhu et al. 2007).

Forest ecosystems play an important role in Chinese vegetation and in carbon cycle regulation. Piao et al. (2005a) estimated a small rate of annual increase (ca. $0.37 \%$ ) of China's forest NPP using the ordinary least squares (OLS) regression method and the normal NDVI. However, new methods based on the geographically weighted regression (GWR) with maximum NDVI estimated that average forest NPP increased by $0.72 \%$ from the 1980 s to the late 1990s with complex spatiotemporal patterns (Wang et al. 2008a).

\section{Future changes}

Climate change

According to recent simulations from different climate models, a general trend over China is that the entire 
country will get warmer, the eastern China and the Tibetan Plateau will get wetter, and northern and northwestern China will get wetter or drier in the future 20-100 years.

Regional climate models (such as the NCAR RegCM2, $\mathrm{RegCM} / \mathrm{China}$ ) project that surface air temperature might increase remarkably, especially during the winter in northern China and on the Tibetan Plateau. Precipitation might also increase in most parts of China under a scenario with a doubling of $\mathrm{CO}_{2}$ concentration $\left(2 \times \mathrm{CO}_{2}\right)(\mathrm{Gao}$ et al. 2001; Chen et al. 2003a). Regional climate-ecosystem models showed that, generally, China tends to be warmer and wetter under doubled $\mathrm{CO}_{2}$ except for inland areas of northern and northwestern China, which become warmer and drier (Chen et al. 2004). Seven climate models using the IPCC SRES A2 and B2 emission scenarios simulated higher surface air temperatures in China in the twenty-first century; however, warming in northeastern, western and central China is stronger and shows large inter-annual variation. Annual and seasonal precipitation increases, but also shows regional and temporal variations (Jiang et al. 2004). Rainfall seasonality strengthens and summer precipitation increases significantly in northern China, implying a risk of flooding in the twenty-first century (Cholaw et al. 2003).

A typical climate scenario for China is shown in Fig. 2, mapping expected changes of temperature (Fig. 2a) and

\section{a Mean annual temperature and anomaly (HADCM2-2100) of China}

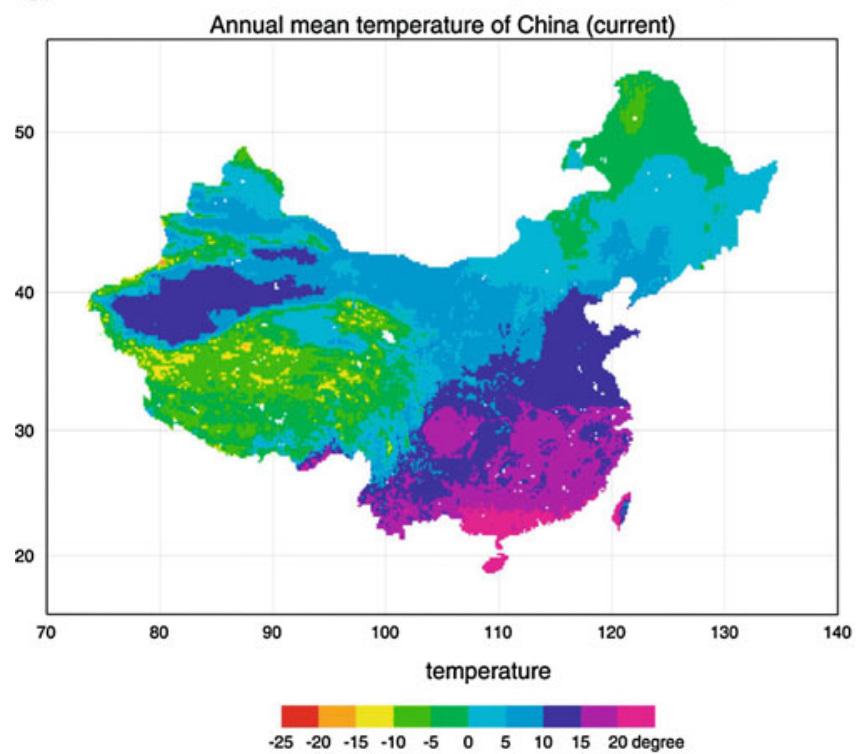

b Mean annual precipitation and anomaly (HADCM2-2100) of China
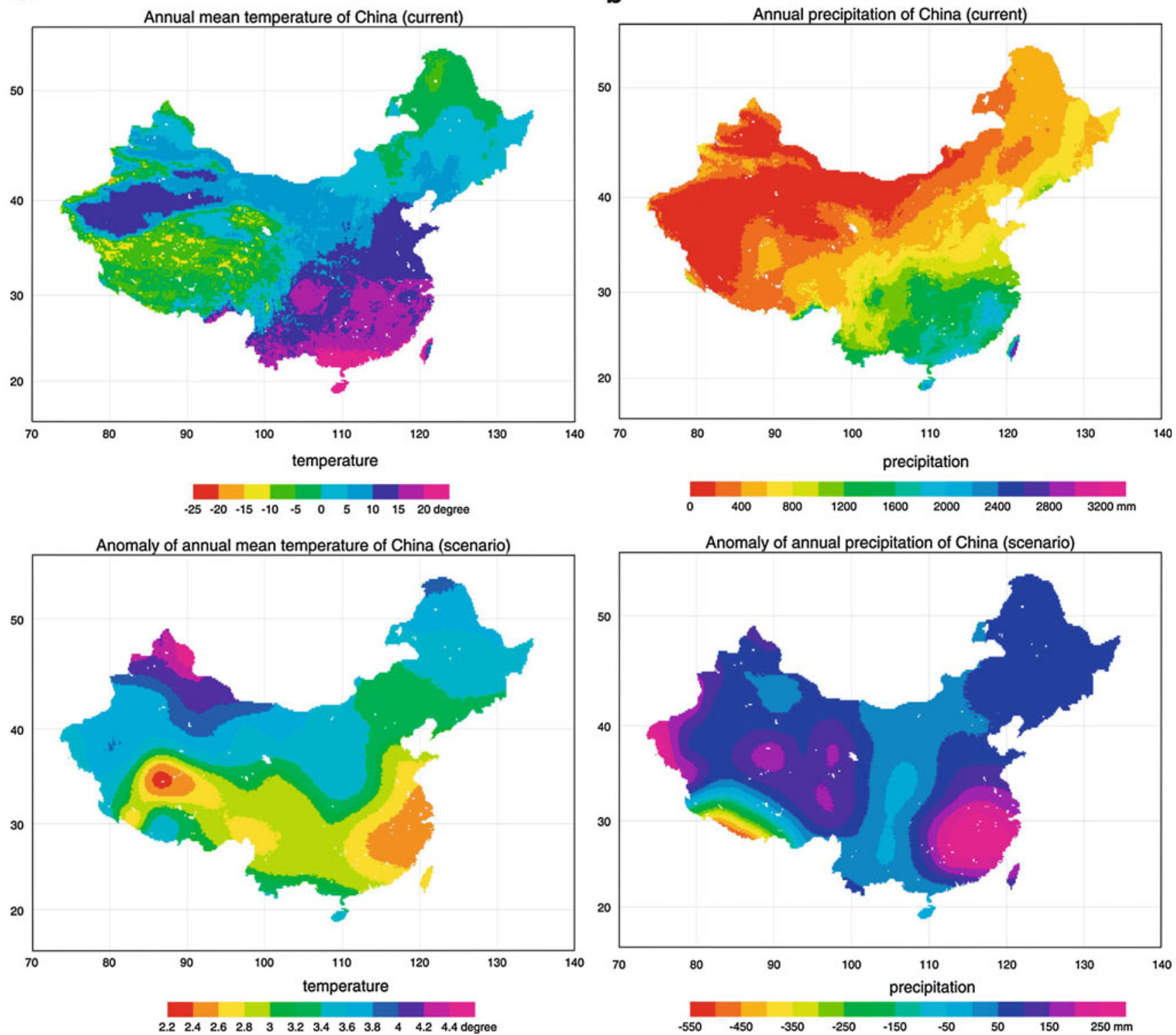

Fig. 2 Climate scenarios for China in 2100 predicted by the HadCM2. a Annual mean temperature (top current, bottom anomaly) and b annual mean precipitation (top current, bottom anomaly) 
precipitation (Fig. 2b) in 2100, based on the HadCM2 model. Annual mean temperature is expected to increase by between 2.2 and $4.4^{\circ} \mathrm{C}$ in the end of the twenty-first century in China. The largest increases $\left(3-4^{\circ} \mathrm{C}\right)$ occur in northeastern and northwestern China, and the median changes $\left(2-3^{\circ} \mathrm{C}\right)$ occur in eastern, southern, southwestern China and on the Tibetan Plateau. The greatest increases occur in winter. Changes in precipitation, ranging between a $506-\mathrm{mm}$ decrease and a $290-\mathrm{mm}$ increase, may be different in regions. Annual precipitation in most areas of China increases, and the largest increment $(>150 \mathrm{~mm})$ may occur in the eastern subtropical area and westernmost part of the Tibet. In central China, however, there may be $0-100 \mathrm{~mm}$ less precipitation. The largest decrease (100-500 mm) occurs in southwestern Tibet.

The combined effects of global warming and direct human impacts have the potential to influence glaciers, permafrost, snow cover and sea level in China. Glaciers are likely to retreat, and many small glaciers may disappear. Snow cover may be lower in plains and higher in mountains, and river run-off may increase with a higher variability (Shi and Zhang 1995). By the year 2100, glaciers are projected to shrink by $45 \%$ (Shi and Liu 2000), and the monsoonal temperate glaciers decrease by $75-80 \%$, representing an area of approximately $9,900 \mathrm{~km}^{2}$ (Su and Shi 2002). Substantial retreat of permafrost is expected on the Tibetan Plateau and in northeastern China (Su and Shi 2002). The relative sealevel rising is to speed up in the twenty-first century ( $\mathrm{Wu}$ et al. 2003), but the future sea-level and its rising rate will be different by seasons (Cui and Zorita 1998) and regions (Chen 1997). This will likely cause environmental problems such as coastal erosion, severe reduction of agricultural production and water shortages (Chen 1997; Chen and Zong 1999; Wu et al. 2003). Climate change and associated soil degradation will modify water resource in China (Kirshen et al. 2005; Tao et al. 2005; Piao et al. 2010), especially in the semi-arid regions of northern, northeastern, and in central, western, and southwestern China, which would become more vulnerable to disastrous drought and floods.

\section{Natural ecosystems}

Simulations with a static vegetation-climate model driven by seven GCM scenarios for 2050 indicate a northward shift of vegetation, with an increase in the extent of tropical rain forests and a decrease of cold-temperate coniferous forest and tundra (Wang and Zhao 1995). Using a processbased equilibrium terrestrial biosphere model (BIOME3), vegetation changes could be projected using a climate scenario for 2099 (HadCM2) along with enhanced $\mathrm{CO}_{2}$ concentration from 340 (Fig. 3b) to 500 ppmv (Fig. 3c) (Ni et al. 2000). Climate change alone produced a large reduction in temperate desert, alpine tundra and ice/desert, and a general poleward shift of the boreal, temperate deciduous, warm-temperate evergreen and tropical forest belts, a decline in boreal deciduous forest and the appearance of tropical deciduous forest (Fig. 3b). The inclusion of $\mathrm{CO}_{2}$ physiological effects led to a marked decrease in moist forest steppe and desert, a general decrease for temperate steppe, and disappearance of xeric woodland/ scrub. Temperate deciduous broadleaved forest, however, shifted north to occupy nearly half the area of previously temperate mixed forest (Fig. 3c). Other model simulations showed similar trends of vegetation shifts and area changes, indicating several vulnerable regions: northern China, northeastern plain, the Tibetan Plateau and southwestern China, as well as the ecotones between different vegetations (Weng and Zhou 2006; Yu et al. 2006). For example, the Mapped Atmosphere-Plant-Soil System (MAPSS) (Zhao et al. 2002) showed that in eastern China, forest boundaries could shift northward, especially the boreal deciduous conifer forest, which may disappear from China. In northern China and the Liaohe River drainage of northeastern China, there would be a large extension of steppe. Desert and steppe in western China will shrink, replaced by steppe and shrubs, respectively. Meadows on the Tibetan Plateau will be reduced (Zhao et al. 2002).

Actual land cover and ecosystem distribution will be affected both by climate change and by human activities and economic policy. During the next 100 years, cultivated land is expected to gradually increase and its mean center will likely shift toward the east in general. Woodland area is expected to increase greatly, especially together with the increase in grassland in the hilly areas, as a consequence of the Grain-for-Green policy (Yue et al. 2007).

The regional pattern of expected ecosystem change differs between assessments. A simulation under doubled $\mathrm{CO}_{2}$ concentration with the NCAR regional climate model (RegCM2) coupled with the CSIRO GCM indicated dramatic changes of Holdridge Life Zones in China (Chen et al. 2003b). The relative area of forests would increase about $15 \%$, but the relative area of desert and alpine vegetation would decrease about 9 and $4 \%$, respectively. New life zones, such as subtropical desert, tropical desert and tropical thorn woodland, would appear. Subtropical evergreen broadleaved forest, tropical rainforest and monsoon forest, and the three new life zones would appear in northeastern China. Cool-temperate mixed coniferous and broadleaved forest and warm-temperate deciduous broadleaved forests would appear at latitudes $25-35^{\circ} \mathrm{N}$. Subtropical evergreen broadleaved forest, warm-temperate deciduous broadleaved forest and temperate steppe, and a large part of alpine vegetation on the Tibetan Plateau would be replaced by tropical rainforest, tropical thorn woodland, subtropical evergreen broadleaved forest, tropical desert and temperate steppe (Chen et al. 2003b). 
Fig. 3 Vegetation of China predicted by BIOME3 model under a current climate condition, $\mathbf{b}$ climate scenario (HadCM2) with $\mathrm{CO}_{2}$ concentration at $340 \mathrm{ppmv}$, and c climate scenario (HadCM2) with $\mathrm{CO}_{2}$ concentration at 500 ppmv (redrawn from $\mathrm{Ni}$ et al. 2000)

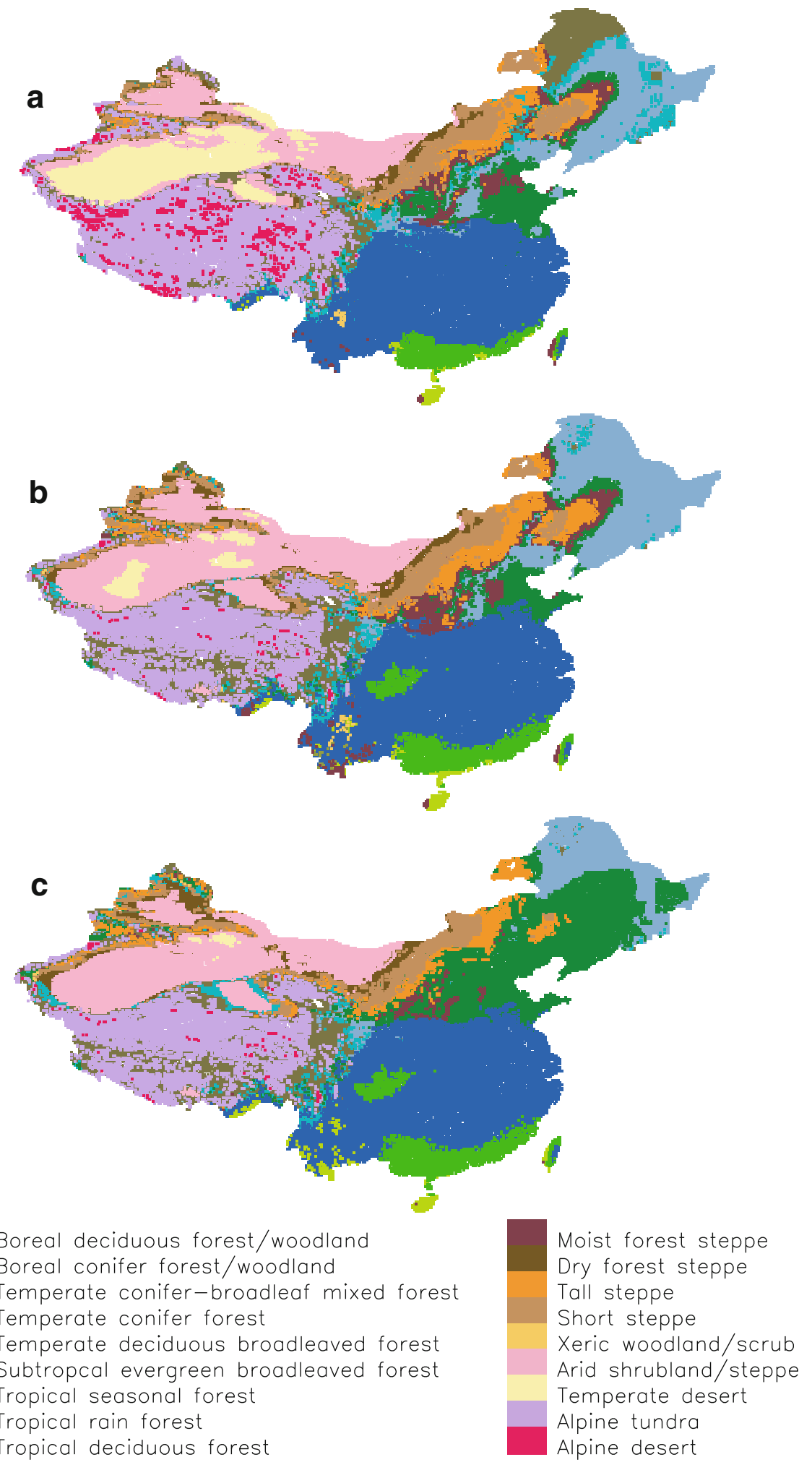

Regional climate-ecosystem models show that under future climate scenarios forced by doubled $\mathrm{CO}_{2}$, temperate deciduous forests expand northward, replacing grassland. Evergreen taiga retreats in the coastal northeast. The largest changes occur in extensive inland regions northward of $40^{\circ} \mathrm{N}$, where deserts and shrubland expand, indicating a marked sensitivity and vulnerability to climatic change (Chen et al. 2004). A regional vegetation dynamic model predicted under a perturbation climate scenario (defined by perturbations from the present climate, $100 \%$ in 
atmospheric $\mathrm{CO}_{2}$ concentration, $2^{\circ} \mathrm{C}$ in monthly mean temperature and $20 \%$ in monthly precipitation) that grasslands, shrubs and conifer forests are more sensitive to environmental changes than evergreen broadleaf forests in warm, wet southeast China and desert vegetation in cold, arid northwest China (Gao et al. 2000).

Regional studies show more detailed and clearer changes in future vegetation pattern, especially in some key vulnerable regions, for example, the northeastern China, eastern China, northern China, northwestern China and the Tibetan Plateau.

\section{Northeastern China}

A biogeographical model driven by elevation, Quaternary geology and a moisture index predicted that along a longitudinal transect in northeastern China under doubled $\mathrm{CO}_{2}$ concentration, forests, shrubs, meadows and swamps will shrink and steppes will enlarge (Li 1995). A satellite-driven vegetation model simulated that, on the same transect, historical climate and a doubling of $\mathrm{CO}_{2}$ concentration would lead to a $25 \%$ increase in overall average NPP, and a $23.4 \%$ increase if a $30 \%$ precipitation increase was superimposed on the doubled $\mathrm{CO}_{2}$ concentration (Gao and Zhang 1997). Further simulation using a dynamic regional vegetation model showed that the average NPP of natural vegetation over the whole region would decrease slightly with doubled $\mathrm{CO}_{2}$ concentration, a $20 \%$ increase in precipitation and a $4{ }^{\circ} \mathrm{C}$ increase in temperature (Gao and $\mathrm{Yu}$ 1998). NPP of Larix forest, conifer-broadleaved mixed forest, Leymus chinense steppe, Stipa grandis steppe, and wetland and salty meadow would decrease by $15-20 \%$. However, NPP of deciduous broadleaf forest, woodland and shrubs, Stipa baicalensis meadow steppe and desert grasslands would increase by 20-115\% (Gao and $\mathrm{Yu}$ 1998). In addition, the Leymus chinense meadow steppe showed contrasting responses to different levels of increases in temperature and precipitation. Under doubled $\mathrm{CO}_{2}$ concentration, NPP would increase by $7-21 \%$ if temperature increases from 2.7 to $3.9^{\circ} \mathrm{C}$ and precipitation increases by $10 \%$, while NPP would decrease by $24 \%$ if temperature increases from 7.5 to $7.8^{\circ} \mathrm{C}$ and precipitation increases by $10 \%$ (Wang et al. 2007).

A forest model (ROPE) simulated that under four climate change scenarios, the Korean pine (Pinus koraiensis) broadleaved mixed forest must be expected to occur only at high elevation in the mountains (Shao et al. 1995). Larch forest would only be found north of the study area. Instead, broadleaved forest would become the dominant vegetation type (Shao et al. 1995). A gap dynamics model (KOPIDE) predicted that climate change would cause important changes in a mixed broadleaved Korean pine forest stand structure. Korean pine, the dominant species in the area under current climate conditions, would disappear. Oak and elm would become the dominant species replacing Korean pine, ash and basswood (Shao 1996). However, an improved, coupled modeling approach that links a gap model (LINKAGES) with a spatially explicit landscape model (LANDIS) predicted that the dominant effects of climate warming were evident on forest ecosystems in the low- and high-elevation areas, but not in the mid-elevation areas (He et al. 2005). In the Changbai Mountain area $\left(4.6^{\circ} \mathrm{C}\right.$ annual temperature increase and little precipitation change), the disappearance of tree species would not be expected within the 300-year simulation period. Neither Korean pine nor spruce-fir was completely replaced by broadleaf species. However, in simulations beyond 300 years, Korean pine, spruce and fir species could eventually be replaced by broadleaf tree species (He et al. 2005).

Stand density, composition and biomass of forest at the ecotone of boreal forest and temperate forest in northeastern China are likely to change during the next 50 years (Chen 2002a). The larch forest will be stressed under a $2^{\circ} \mathrm{C}$ temperature increase and a $10 \%$ precipitation increase, but it will withstand a $2^{\circ} \mathrm{C}$ temperature increase and a $10 \%$ precipitation decrease. However, the Korean pine and broadleaf mixed forest will withstand the former condition, but be stressed under the latter condition (Chen 2002b). Alpha tree diversity (species evenness) would decrease under climate change (annual temperature $+2^{\circ} \mathrm{C}$, annual precipitation $-10 \%$ and $\mathrm{CO}_{2}$ concentration at 700 ppmv), but would increase significantly under a combination of climate change and logging. Beta diversity (changes of species number over time) however would increase significantly under climate change and climate change plus logging (Chen and Li 2003, 2004).

Species in northeastern China are expected to change their geographical patterns under climate change. Based on the averages of rainfall and temperature simulated by five GCMs for the year 2030, an ecological information system (GREEN) predicted that the future distribution of Korean pine will shift northward, and the potential distribution area will expand by $3.4 \%$. However, its area will decrease by 12.1 and $44.9 \%$ under another climate scenario and annual increments of $\mathrm{CO}_{2}$ concentrations of 0.5 and $1 \%$, respectively (Xu and Yan 2001). Dahurian larch (Larix gmelini) and Korean larch (Larix olgensis var. changpaiensis) will retreat northwestward by $90-140$ and $100-340 \mathrm{~km}$, respectively, with large decreases in their potential areas. The Prince Rupprecht larch (Larix principis-rupprechtii) however would disappear from NE China (Leng et al. 2008). Similar result from BIOME3 simulation, showing the temperate deciduous forest expands to the cold-temperate region and the mixed deciduous-coniferous forest shrinks under HadCM2 climate (Ni et al. 2000), confirming 
that the decrease of pine and larch forests in this area is likely to happen.

\section{Eastern China}

A regional dynamic vegetation model including biogeochemical cycling of nitrogen (Yu et al. 2002) and land use (Gao et al. 2003) was applied to the forest-rich region in eastern China. The simulations from seven GCMs-projected future climate scenarios with doubled atmospheric $\mathrm{CO}_{2}$ concentration predicted that broadleaved forests would increase, but conifer forests, shrubs and grasses would decrease, and that deciduous forests would have the largest relative increase, while evergreen shrubs would have the largest decrease. The overall effects of doubling $\mathrm{CO}_{2}$ and climatic changes also increase NPP for all seven GCM scenarios (Yu et al. 2002; Gao et al. 2003).

\section{Northern China}

Grasslands in Inner Mongolia are vulnerable to both climate change and grazing (Christensen et al. 2004). An ecosystem model simulated that herbaceous aboveground NPP is most sensitive to changes in precipitation. Combinations of increased precipitation, temperature and $\mathrm{CO}_{2}$ had synergistic effects on herbaceous production; however, drastic increases in these climate scenarios result in the system shifting from herbaceous to shrub-dominated vegetation when grazed. Reduced precipitation has a negative effect on vegetation growth rates. Shifts in biomass patterns due to changes in climate have potentially significant implications for grazing management, which will need to be altered under changing climate in order to maintain system stability (Christensen et al. 2004). A previously simulation using the CENTURY ecosystem model also showed that the effects of global climate change and doubled atmospheric $\mathrm{CO}_{2}$ concentration led to loss of NPP and soil organic matter of typical steppe (Leymus chinense, Stipa grandis) and meadow steppe (Filifolium sibiricum, S. baicalensis and L. chinense) in Inner Mongolia (Xiao et al. 1995).

\section{Northwestern China}

Northwestern China is also a key vulnerable region because the annual temperature will increase by $2^{\circ} \mathrm{C}$ when taking both the global warming and cooling effect of aerosols into account (Shi et al. 2007). Regional vegetation changes in this area were only indicated by country-level simulations, so far there is no publication available from regional prediction. However, BIOME-BGC model-simulated forest NPP of Picea schrenkiana in the Tianshan Mountains, Xinjiang Autonomous Region would dramatically increase by $26-37 \%$ when considering both the increases of temperature and precipitation and the doubling of $\mathrm{CO}_{2}$ concentration ( $\mathrm{Su}$ et al. 2007).

\section{Tibetan Plateau}

The Tibetan Plateau has unique, extreme environments that are most sensitive and vulnerable to climate change and human disturbances. The improved BIOME3 model was used to simulate the responses of biomes on the Tibetan Plateau to climate change (HadCM2) and doubled $\mathrm{CO}_{2}$ concentration $(500 \mathrm{ppm})$ in the end of twenty-first century (Ni 2000). The climate change would cause a large reduction in the temperate deserts, alpine steppe, alpine desert and ice, a large increase in the cold-temperate conifer forest, temperate shrub meadow and temperate steppe, and a general northwestward shift of all vegetation zones (Fig. 4). The disappearance of permafrost would accelerate desertification (Ni 2000). The improved BIOME4 model was also applied to the Tibetan Plateau under the HadCM3 climate scenario during the twenty-first century (Song et al. 2005). Increased $\mathrm{CO}_{2}$ concentration would potentially lead to big changes in alpine ecosystems. There will be a major
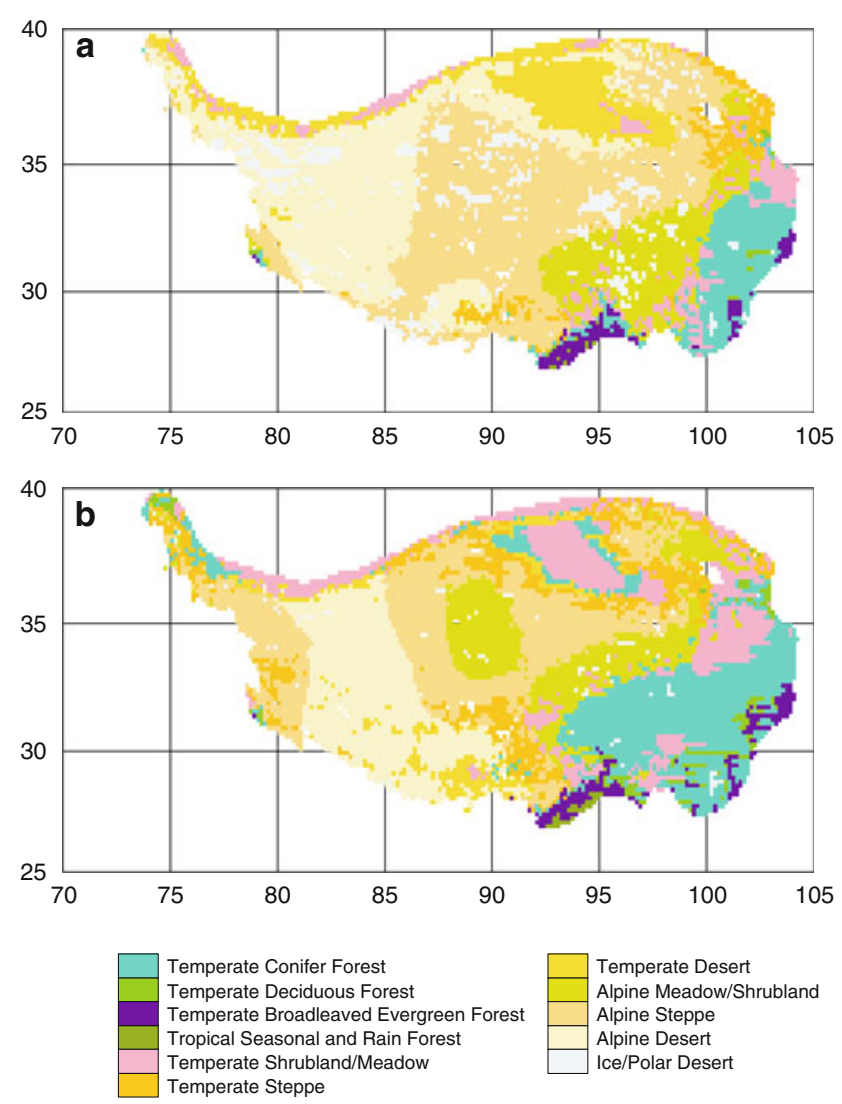

Fig. 4 Vegetation changes on the Tibetan Plateau under a current climate and $\mathbf{b}$ climate scenario with $\mathrm{CO}_{2}$ concentration at 500 ppmv (from Ni 2000) 
northward shift of alpine meadow and a reduction in shrubdominated montane steppe. The area of alpine desert would decrease, and of the montane desert would increase.

Future changes on the Tibetan Plateau will not only occur in vegetation patterns but also to species distribution. Under a climate scenario with the $\mathrm{CO}_{2}$ concentration of 500 ppmv in year 2100 (HadCM3), a bioclimatic model predicted that the distribution of the tree species (Abies spectabilis, Picea likiangensis var. linzhiensis, Pinus densata, Larix griffithiana and Quercus aquifolioides) would shift and extend northward and westward, and Betula utilis would shift northward with some area shrinkage (Song et al. 2004). On the other hand, the independent and combined effects of field experimental warming and grazing on the northeastern Tibetan Plateau indicate that these could cause dramatic declines in plant species diversity in high elevation meadows over short time frames (Klein et al. 2004).

\section{Discussion}

Historical observations and reconstructions confirm that climate change has occurred in China. Temperature has commonly increased in the entire country during the past century. Precipitation has generally increased in the country during the recent 50 years, but with strong temporal and spatial variations in both magnitude and frequency. More droughts occurred in northern China and more floods did in southern China. Such changes in climate (associated with land use changes) led to changes of terrestrial ecosystems. Generally speaking, plant phenology in spring has advanced due to climate warming. The growing season of vegetation has lengthened. The composition and geographical pattern of vegetation have been changed, especially in ecotone and tree-line. Climate change has resulted in the increases of vegetation cover, vegetation activity and net primary productivity in the whole country.

Climate model projections all show plausible climate scenarios in the future for China. Increases in temperature and changes in precipitation regime are certain. The projected climate scenarios (associated with land use changes again) will significantly influence Chinese ecosystems. To summarize, future impacts of projected climate change (including changes in temperature, precipitation and $\mathrm{CO}_{2}$ concentration) will include a northward shift of all forests; disappearance of boreal forest from northeastern China; new tropical forests and woodlands move into the tropics; an eastward shift of grasslands (expansion) and deserts (shrinkage); a reduction of alpine vegetation; and an increase in net primary productivity of most vegetation types. Ecosystems in northern and western parts of China are more vulnerable to climate changes than those in eastern China, while ecosystems in the east are more vulnerable to land use changes other than climate changes.

However, simulation of terrestrial ecosystems response to climate change are highly constrained by current vegetation patterns, correct understanding of ecophysiological and bioclimatic features of vegetation, the spatial and temporal resolution of the simulations, the structure and mechanism of vegetation models, whether equilibrium or dynamic ones, general circulation models (global or regional), future changes of greenhouse gas concentration and climate scenarios (Wang and Zhao 1995; Ni et al. 2000; Xu and Yan 2001; Gao et al. 2000, 2004). For example, at the national scale, comparisons between biome simulations using BIOME3 ( $\mathrm{Ni}$ et al. 2000) and MAPSS (Zhao et al. 2002) both under the HadCM2 scenario, and vegetation predictions using the Holdridge Life Zone Systems under the CSIRO GCM (Chen et al. 2003b) and the HadCM2/HadCM3 scenarios (Yue et al. 2006), showed that the former captures well the current biome distribution and their future changes but the later did not do this well. Chen et al. (2003b) predicted the long-distance shifts of subtropical/tropical forests (northeastward) and temperate forests (southward), and the dramatic changes of temperate deserts and alpine vegetation. Yue et al. (2006) also predicted the large shift ranges of boreal wet forest, subtropical moist forest, tropical dry forest, warm-temperate moist forest and subtropical wet forest. These dramatic changes are to some extent not plausible. Several reasons can explain the difference among these simulations. (1) Different mechanisms behind vegetation models: the BIOME3 and MAPSS are processed-based vegetation models, which include both ecophysiological and biogeochemical processes such as carbon and water cycles, photosynthesis and respiration, and plant competition, as well as bioclimate features of vegetation. However, the Holdridge Life Zone System is a static model which only has bioclimatic controls of vegetation pattern. The different processes and behavior of models make the predictions different. The model comparisons are therefore important (Cramer et al. 1999, 2001). (2) Differences in vegetation classification: BIOME3 and MAPSS use the common global biome classification that captures the major types of Chinese vegetation, but the life zones are too fine and their definitions are not clear in Chinese ecosystems. (3) Limitation in GCMs and difference in climate scenarios. Such limitations and differences obviously influence vegetation model simulations. On the other hand, vegetation models have their own limitations, especially in the detailed ecological processes and on individual species such as current knowledge of species distribution, climate tolerance and characteristics of seed dispersal and life cycle. For instance, seed dispersal has strong impact on the direction and time of vegetation migration, which are important to 


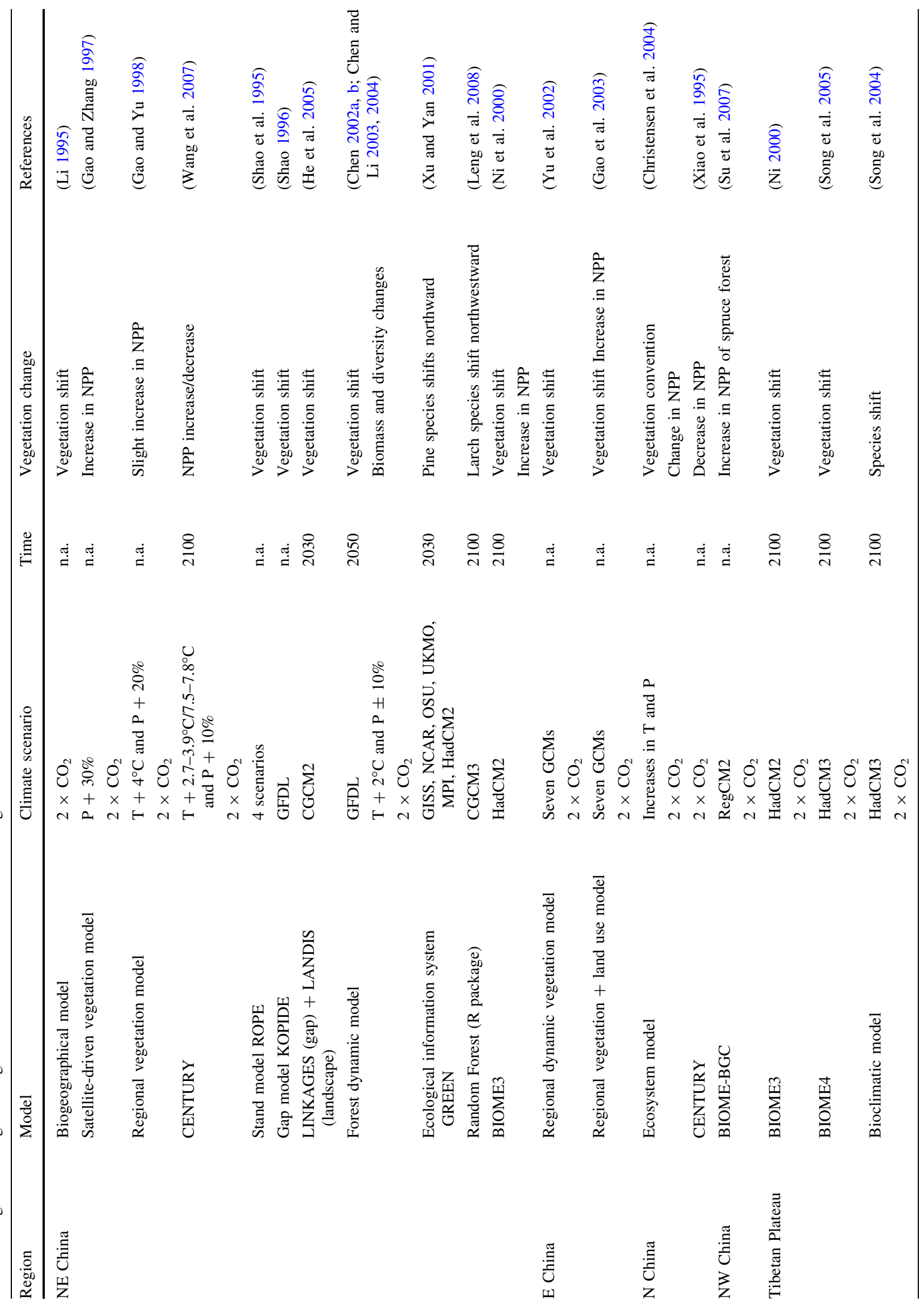


vegetation models, but so far only a few vegetation models include the plant dispersal function that determines how fast and far might plant and vegetation migrate due to climate change (e.g., Iverson et al. 2004). Furthermore, human activities have the power to modify the behavior of ecosystem responses to climate change. Strong effects of both land use changes (Liu et al. 2005b) and rapid urbanization (Zhao et al. 2006; Chen 2007) in China cannot be ignored in the predictions of future development of Chinese ecosystems under the impacts of climate changes.

Impacts of climate change on vegetation and the responses and feedbacks of vegetation to climate change depend on the different types of regional vegetation and species composition. It is therefore difficult to draw a general and more accurate picture of the potential impacts of climate change on Chinese vegetation, especially to determine accurate thresholds, because all predictions were made by a variety of vegetation and climate models. However, a summary table is still synthesized in this paper (Table 1).

A major concern about global change is global warming (Hare 2003). The European Union recently adopted $2^{\circ} \mathrm{C}$ global mean warming above preindustrial as a target (European Climate Forum 2005). In this paper, changes in Chinese vegetation under a $2^{\circ} \mathrm{C}$ warming are briefly summarized (Table 2). Bear in mind that the $2^{\circ} \mathrm{C}$ warming is above the mean temperature of the past 30-50 years, as usually used by most Chinese vegetation modelers.

Impacts of climate change on Chinese ecosystems are both region-dependent and vegetation-dependent. The vulnerability of conifer forest, desert, steppe and tundra ecosystems in northern and western China including the Tibetan Plateau is greater than in eastern and southern China where deciduous and evergreen forests dominate the landscape. Northern China will likely suffer drought stress in the future. Desertification is a critical problem in northern and northwestern China and on the Tibetan Plateau. China has made great efforts to combat desertification. Improvements have occurred in some areas (Yang et al. 2005). Remote sensing data show that desertification has declined in the past two decades (Piao et al. 2005b), but an assessment indicates desertification continues to increase (Yang et al. 2005; Wang et al. 2008b). Land use and land management (such as overgrazing and cultivation) as well as aridity have led to more desertified land in the semiarid northern region ( $\mathrm{Li}$ et al. 2000; Chen and Tang 2005; Zheng et al. 2006b) and even in the arid west (Wang et al. 2006). Permafrost degradation and human activities have also contributed to further desertification on the Tibetan Plateau (Yang et al. 2004b). Changes in Quaternary geological environment and climate were considered to be decisive factors for desertification (over 1,000-

Table 2 Changes in Chinese ecosystems and species below and above $2^{\circ} \mathrm{C}$ warming

\begin{tabular}{|c|c|c|}
\hline $\begin{array}{l}\text { Temperature } \\
\text { increase }\left({ }^{\circ} \mathrm{C}\right)\end{array}$ & Changes in ecosystems & Changes in species \\
\hline$<2$ & $\begin{array}{l}\text { Northward shift of vegetation, with an expansion of tropical } \\
\text { rain forests and decrease of cold-temperate coniferous forests } \\
\text { and tundra by } 2050 \text {. Broadleaved forests increase, but } \\
\text { coniferous forests, shrubs and grasses decrease in eastern } \\
\text { China. Forest NPP increases } 1.5-2 \text { ton/hectare/year }\end{array}$ & \\
\hline \multirow[t]{3}{*}{$>2$} & $\begin{array}{l}\text { Vegetation composition changes, net primary productivity } \\
\text { increases, and tree biodiversity increases or decreases (varies } \\
\text { upon forest management) in the mixed broadleaved Korean } \\
\text { pine forest in northeastern China by } 2050\end{array}$ & $\begin{array}{l}\text { Korean pine (Pinus koraiensis) distribution decreases by } \\
12-45 \% \text { in northeastern China by } 2030\end{array}$ \\
\hline & $\begin{array}{l}\text { Grasslands, shrubs and conifer forests are more sensitive to } \\
\text { environmental changes than evergreen broadleaf forests in } \\
\text { warm, wet southeast China and desert vegetation in cold, arid } \\
\text { northwest China. NPP increases or decreases }\end{array}$ & \\
\hline & $\begin{array}{l}\text { Herb NPP decreases and shrub NPP increases in the Inner } \\
\text { Mongolian steppe }\end{array}$ & \\
\hline $2-3$ & $\begin{array}{l}\text { Forests increase by } 15 \% \text {. Subtropical and tropical deserts and } \\
\text { woodland appear. Temperate, subtropical and tropical forests } \\
\text { dramatically, long-distanced shifts to the north. Desert and } \\
\text { alpine vegetation decrease by } 9 \text { and } 4 \% \text {, respectively }\end{array}$ & $\begin{array}{l}\text { Distribution of dominant conifer tree species (Abies spectabilis, } \\
\text { Picea likiangensis var. linzhiensis, Pinus densata, Larix } \\
\text { griffithiana) shift and extend northward and westward, and } \\
\text { deciduous tree (Betula utilis) shifts northward but its area } \\
\text { shrinks on the Tibetan Plateau by } 2100\end{array}$ \\
\hline $3-4$ & $\begin{array}{l}\text { A large reduction in desert and alpine tundra, a general decrease } \\
\text { in steppe, and a general poleward shift of boreal, temperate } \\
\text { deciduous, warm-temperate evergreen and tropical forests, a } \\
\text { decline in boreal deciduous forest and the appearance of } \\
\text { tropical deciduous forest. NPP increases by } 2100\end{array}$ & \\
\hline
\end{tabular}


10,000 years timescale). The destruction of the vegetation and surface soil cover driven by recent human influence (10-100 years) is the direct and immediate cause leading to the present state of desertification (Lin and Tang 2002). If the climate gets warmer and wetter in northern and northwestern China as predicted by climate models and if human activities can be reduced in these regions, desertification could likely be controlled in the future. Otherwise drier climate and further land use in the north could increase desertification (Chen and Tang 2005). On the Tibetan Plateau, warmer and wetter climates will reduce continuous permafrost and speed up land degradation and desertification (Ni 2000).

In eastern China, various coniferous forests and broadleaf forests are distributed from the northeastern to the southern areas. Climates in this region are adequate for plant growth, both under current and future condition. Ecosystems are less vulnerable to projected climate changes than those in northern and western China. However, historical human activities have greatly modified the natural environment in this area, through cultivation, plantation and urbanization (Piao et al. 2003a; Liu et al. 2005b; Zhao et al. 2006; Chen 2007). Natural vegetation is almost entirely restricted to mountainous areas and national reserves. Therefore, ecosystems in the eastern half of the country are more vulnerable to future land use changes rather than to climate changes. Any simulations of ecosystem changes in this region must take land use changes into account (Gao et al. 2003).

Acknowledgments This study was supported by the National Basic Research Program of China (2010CB951303) and the German Research Foundation (DFG, He 3622/6). I am grateful to Bill Hare, Wolfgang Cramer, Dominique Bachelet and one anonymous reviewer for their useful comments and suggestions on the early version of this paper.

\section{References}

Che HZ, Shi GY, Zhang XY, Arimoto R, Zhao JQ, Xu L, Wang B, Chen ZH (2005) Analysis of 40 years of solar radiation data from China, 1961-2000. Geophys Res Lett 32:L06803

Chen JY (1997) The impact of sea level rise on China's coastal areas and its disaster hazard evaluation. J Coast Res 13(3):925-930

Chen XW (2000) Characteristic change of several forest landscapes between 1896 and 1986 in Heilongjiang Province. Acta Bot Sin 42(9):979-984

Chen XW (2001) Change of tree diversity on Northeast China Transect (NECT). Biodivers Conserv 10(7):1087-1096

Chen XW (2002a) Modeling the effects of global climatic change at the ecotone of boreal larch forest and temperate forest in Northeast China. Clim Chang 55(1-2):77-97

Chen XW (2002b) Study of the ecological safety of the forest in northeast China under climate change. Int J Sustain Dev World Ecol 9(1):49-58

Chen J (2007) Rapid urbanization in China: a real challenge to soil protection and food security. Catena 69(1):1-15
Chen XW, Li BL (2003) Effect of global climate change and human disturbances on tree diversity of the forest regenerating from clear-cuts of mixed broadleaved Korean pine forest in Northeast China. Chemosphere 51(3):215-226

Chen X, Li B-L (2004) Tree diversity change in remaining primary mixed-broadleaved Korean pine forest under climate change and human activities. Biodivers Conserv 13(3):563-577

Chen XQ, Pan WF (2002) Relationships among phenological growing season, time-integrated normalized difference vegetation index and climate forcing in the temperate region of eastern China. Int J Climatol 22(14):1781-1792

Chen Y, Tang H (2005) Desertification in north China: background, anthropogenic impacts and failures in combating it. Land Degrad Dev 16(4):367-376

Chen X, Zong Y (1999) Major impacts of sea-level rise on agriculture in the Yangtze delta area around Shanghai. Appl Geogr 19(1):69-84

Chen XW, Zhang XS, Zhou GS, Chen JZ (2000) Spatial characteristics and change for tree species (genera) along Northeast China Transect (NECT). Acta Bot Sin 42(10):1075-1081

Chen B, Chao WC, Liu X (2003a) Enhanced climatic warming in the Tibetan Plateau due to doubling $\mathrm{CO}_{2}$ : a model study. Clim Dyn 20(4):401-413

Chen XW, Zhang XS, Li BL (2003b) The possible response of life zones in China under global climate change. Glob Planet Chang 38(3-4):327-337

Chen XW, Zhou GS, Zhang XS (2003c) Spatial characteristics and change for tree species along the North East China Transect (NECT). Plant Ecol 164(1):65-74

Chen M, Pollard D, Barron EJ (2004) Regional climate change in East Asia simulated by an interactive atmosphere-soil vegetation model. J Clim 17(3):557-572

Chen XQ, Hu B, Yu R (2005) Spatial and temporal variation of phenological growing season and climate change impacts in temperate eastern China. Glob Chang Biol 11(7):1118-1130

Cholaw B, Cubasch U, Lin YH, Ji LR (2003) The change of North China climate in transient simulations using the IPCC SRES A2 and B2 scenarios with a coupled atmosphere-ocean general circulation model. Adv Atmos Sci 20(5):755-766

Christensen L, Coughenour MB, Ellis JE, Chen ZZ (2004) Vulnerability of the Asian typical steppe to grazing and climate change. Clim Chang 63(3):351-368

Cramer W, Kicklighter DW, Bondeau A, Moore B, Churkina C, Nemry B, Ruimy A, Schloss AL, Intercompariso PPNM (1999) Comparing global models of terrestrial net primary productivity (NPP): overview and key results. Glob Chang Biol 5:1-15

Cramer W, Bondeau A, Woodward FI, Prentice IC, Betts RA, Brovkin V, Cox PM, Fisher V, Foley JA, Friend AD, Kucharik C, Lomas MR, Ramankutty N, Sitch S, Smith B, White A, Young-Molling C (2001) Global response of terrestrial ecosystem structure and function to $\mathrm{CO}_{2}$ and climate change: results from six dynamic global vegetation models. Glob Chang Biol 7(4):357-373

Cui MC, Zorita E (1998) Analysis of the sea-level variability along the Chinese coast and estimation of the impact of a $\mathrm{CO}_{2^{-}}$ perturbed atmospheric circulation. Tellus A Dyn Meteorol Oceanogr 50(3):333-347

Du MY, Kawashima S, Yonemura S, Zhang XZ, Chen SB (2004) Mutual influence between human activities and climate change in the Tibetan Plateau during recent years. Glob Planet Chang 41(3-4):241-249

European Climate Forum (2005) The 2 degrees strategy. ECF, Potsdam

Fang JY, Piao S, Field CB, Pan Y, Guo QH, Zhou LM, Peng CH, Tao $\mathrm{S}$ (2003) Increasing net primary production in China from 1982 to 1999. Front Ecol Environ 1(6):293-297 
Fang JY, Piao SL, He JS, Ma WH (2004) Increasing terrestrial vegetation activity in China, 1982-1999. Sci China C Life Sci 47(3):229-240

Fang JY, Piao SL, Zhou LM, He JS, Wei FY, Myneni RB, Tucker CJ, Tan K (2005) Precipitation patterns alter growth of temperate vegetation. Geophys Res Lett 32:L21411

Fu GB, Chen SL, Liu CM, Shepard D (2004) Hydro-climatic trends of the Yellow River basin for the last 50 years. Clim Chang 65(1-2):149-178

Gao Q, Yu M (1998) A model of regional vegetation dynamics and its application to the study of Northeast China Transect (NECT) responses to global change. Global Biogeochem Cycles 12(2): 329-344

Gao Q, Zhang XS (1997) A simulation study of responses of the northeast China transect to elevated $\mathrm{CO}_{2}$ and climate change. Ecol Appl 7(2):470-483

Gao Q, Yu M, Yang XS (2000) An analysis of sensitivity of terrestrial ecosystems in China to climatic change using spatial simulation. Clim Chang 47(4):373-400

Gao XJ, Zhao ZC, Ding YH, Huang RH, Giorgi F (2001) Climate change due to greenhouse effects in China as simulated by a regional climate model. Adv Atmos Sci 18(6):1224-1230

Gao Q, Li XB, Yang XS (2003) Responses of vegetation and primary production in north-south transect of eastern China to global change under land use constraint. Acta Bot Sin 45(11): 1274-1284

Gao Q, Yu M, Wang JH, Jia HK, Wang K (2004) Relationships between regional primary production and vegetation patterns. Ecol Modell 172(1):1-12

Gao G, Chen DL, Xu CY, Simelton E (2007) Trend of estimated actual evapotranspiration over China during 1960-2002. J Geophys Res 112:D11120

Gemmer M, Becker S, Jiang T (2004) Observed monthly precipitation trends in China 1951-2002. Theor Appl Climatol 77(1-2):39-45

Gong DY, Wang SW (2000) Severe summer rainfall in China associated with enhanced global warming. Clim Res 16(1): $51-59$

Gong DY, Pan YZ, Wang JA (2004a) Changes in extreme daily mean temperatures in summer in eastern China during 1955-2000. Theor Appl Climatol 77(1-2):25-37

Gong DY, Shi PJ, Wang JA (2004b) Daily precipitation changes in the semi-arid region over northern China. J Arid Environ 59(4):771-784

Hare W (2003) Assessment of knowledge on impacts of climate change-contribution to the specification of Art. 2 of the UNFCCC. Externe Expertise für das WBGU-Sondergutachten "Welt im Wandel: Über Kioto hinausdenken. Klimaschutzstrategien für das 21. Jahrhundert". Wissenschaftlicher Beirat der Bundesregierung Globale Umweltveränderungen, Berlin

He YQ, Zhang ZL, Theakstone WH, Chen T, Yao TD, Pang HX (2003) Changing features of the climate and glaciers in China's monsoonal temperate glacier region. J Geophys Res 108(D17): 4530

He HS, Hao ZQ, Mladenoff DJ, Shao GF, Hu YM, Chang Y (2005) Simulating forest ecosystem response to climate warming incorporating spatial effects in north-eastern China. J Biogeogr 32(12):2043-2056

Hu ZZ, Yang S, Wu RG (2003) Long-term climate variations in China and global warming signals. J Geophys Res 108(D19): 4614

Iverson LR, Schwartz MW, Prasad AM (2004) How fast and far might tree species migrate in the eastern United States due to climate change? Global Ecol Biogeogr 13(3):209-219

Jiang DB, Wang HJ, Lang XM (2004) East Asian climate change trend under global warming background. Chin J Geophys Chin Ed 47(4):590-596
Jin HJ, Li SX, Cheng GD, Wang SL, Li X (2000) Permafrost and climatic change in China. Global Planet Change 26(4):387-404

Kirshen P, McCluskey M, Vogel R, Strzepek K (2005) Global analysis of changes in water supply yields and costs under climate change: a case study in China. Clim Chang 68(3):303-330

Klein JA, Harte J, Zhao XQ (2004) Experimental warming causes large and rapid species loss, dampened by simulated grazing, on the Tibetan Plateau. Ecol Lett 7(12):1170-1179

Leng WF, He HS, Bu RC, Dai LM, Hu YM, Wang XG (2008) Predicting the distributions of suitable habitat for three larch species under climate warming in Northeastern China. For Ecol Manage 254(3):420-428

Li X (1995) Modelling the response of vegetation in North-East China transect to global change. J Biogeogr 22(2-3):515-522

Li PJ (1999) Variation of snow water resources in northwestern China, 1951-1997. Sci China Ser D Earth Sci 42:72-79

Li SG, Harazono Y, Oikawa T, Zhao HL, He ZY, Chang XL (2000) Grassland desertification by grazing and the resulting micrometeorological changes in Inner Mongolia. Agric For Meteorol 102(2-3):125-137

Li L, Xu JD, Cai RS (2002) Trends of sea level rise in the South China Sea during the 1990s: an altimetry result. Chin Sci Bull 47(7):582-585

Lin NF, Tang J (2002) Geological environment and causes for desertification in arid-semiarid regions in China. Environ Geol 41(7):806-815

Liu CM, Zheng HX (2004) Changes in components of the hydrological cycle in the Yellow River basin during the second half of the 20th century. Hydrol Process 18(12):2337-2345

Liu CH, Kang ES, Liu SY, Chen JM, Liu ZX (1999) Study on the glacier variation and its runoff responses in the arid region of Northwest China. Sci China Ser D Earth Sci 42:64-71

Liu SY, Sun WX, Shen YP, Li G (2003) Glacier changes since the Little Ice Age maximum in the western Qilian Shan, northwest China, and consequences of glacier runoff for water supply. J Glaciol 49(164):117-124

Liu BH, Xu M, Henderson M, Gong WG (2004) A spatial analysis of pan evaporation trends in China, 1955-2000. J Geophys Res 109:D15102

Liu BH, Xu M, Henderson M, Qi Y (2005a) Observed trends of precipitation amount, frequency, and intensity in China, 1960-2000. J Geophys Res 110:D08103

Liu JY, Tian HQ, Liu ML, Zhuang DF, Melillo JM, Zhang ZX (2005b) China's changing landscape during the 1990s: largescale land transformations estimated with satellite data. Geophys Res Lett 32:L02405

Liu XD, Yin ZY, Shao XM, Qin NS (2006) Temporal trends and variability of daily maximum and minimum, extreme temperature events, and growing season length over the eastern and central Tibetan Plateau during 1961-2003. J Geophys Res 111:D19109

Luo ZK, Sun OJ, Ge QS, Xu WT, Zheng JY (2007) Phenological responses of plants to climate change in an urban environment. Ecol Res 22(3):507-514

Ni J (2000) A simulation of biomes on the Tibetan Plateau and their responses to global climate change. Mt Res Dev 20(1):80-89

Ni J, Sykes MT, Prentice IC, Cramer W (2000) Modelling the vegetation of China using the process-based equilibrium terrestrial biosphere model BIOME3. Global Ecol Biogeogr 9(6):463-479

Piao S, Fang J, Zhou L, Guo Q, Henderson M, Ji W, Li Y, Tao S (2003a) Interannual variations of monthly, seasonal normalized difference vegetation index (NDVI) in China from 1982 to 1999. J Geophys Res 108(14):4401

Piao SL, Fang JY, Chen AP (2003b) Seasonal dynamics of terrestrial net primary production in response to climate changes in China. Acta Bot Sin 45(3):269-275 
Piao SL, Fang JY, Ji W, Guo QH, Ke JH, Tao S (2004) Variation in a satellite-based vegetation index in relation to climate in China. J Veg Sci 15(2):219-226

Piao S, Fang J, Zhu B, Tan K (2005a) Forest biomass carbon stocks in China over the past 2 decades: estimation based on integrated inventory and satellite data. J Geophys Res 110:G01006

Piao SL, Fang JY, Liu HY, Zhu B (2005b) NDVI-indicated decline in desertification in China in the past two decades. Geophys Res Lett 32:L06402

Piao SL, Fang JY, Zhou LM, Zhu B, Tan K, Tao S (2005c) Changes in vegetation net primary productivity from 1982 to 1999 in China. Global Biogeochem Cycles 19:GB2027

Piao SL, Fang JY, Zhou LM, Ciais P, Zhu B (2006) Variations in satellite-derived phenology in China's temperate vegetation. Global Chang Biol 12(4):672-685

Piao S, Ciais P, Huang Y, Shen Z, Peng S, Li J, Zhou L, Liu H, Ma Y, Ding Y, Friedlingstein P, Liu C, Tan K, Yu Y, Zhang T, Fang J (2010) The impacts of climate change on water resources and agriculture in China. Nature 467:43-51

Qian WH, Lin X (2004) Regional trends in recent temperature indices in China. Clim Res 27(2):119-134

Qian WH, Qin A (2008) Precipitation division, climate shift in China from 1960 to 2000. Theor Appl Climatol 93(1-2):1-17

Qian WH, Zhu YF (2001) Climate change in China from 1880 to 1998 and its impact on the environmental condition. Clim Chang 50(4):419-444

Qian WH, Lin X, Zhu YF, Xu Y, Fu JL (2007) Climatic regime shift and decadal anomalous events in China. Clim Chang 84(2): 167-189

Ren ME (1993) Relative sea-level changes in China over the last 80 years. J Coast Res 9(1):229-241

Scholze M, Knorr W, Arnell NW, Prentice IC (2006) A climatechange risk analysis for world ecosystems. Proc Nat Acad Sci U S A 103(35):13116-13120

Schröter D, Cramer W, Leemans R, Prentice IC, Araujo MB, Arnell NW, Bondeau A, Bugmann H, Carter TR, Gracia CA, de la Vega-Leinert AC, Erhard M, Ewert F, Glendining M, House JI, Kankaanpää S, Klein RJT, Lavorel S, Lindner M, Metzger MJ, Meyer J, Mitchell TD, Reginster I, Rounsevell M, Sabate S, Sitch S, Smith B, Smith J, Smith P, Sykes MT, Thonicke K, Thuiller W, Tuck G, Zaehle S, Zierl B (2005) Ecosystem service supply and vulnerability to global change in Europe. Science 310(5752):1333-1337. doi:10.1126/science.1115233

Schwartz MD, Chen ZQ (2002) Examining the onset of spring in China. Clim Res 21(2):157-164

Shao GF (1996) Potential impacts of climate change on a mixed broadleaved-Korean pine forest stand: a gap model approach. Clim Chang 34(2):263-268

Shao GF, Shugart HH, Smith TM (1995) A role-type model (rope) and its application in assessing climate change impacts on forest landscapes. Vegetation 121(1-2):135-146

Shen DJ, Varis O (2001) Climate change in China. Ambio 30(6): 381-383

Shi YF, Liu SY (2000) Estimation on the response of glaciers in China to the global warming in the 21st century. Chin Sci Bull 45(7):668-672

Shi YF, Zhang XS (1995) Impact of climate change on surface-water resource and tendency, in the future in the arid zone of Northwestern China. Sci China Ser B Chem 38(11):1395-1408

Shi YF, Shen YP, Kang E, Li DL, Ding YJ, Zhang GW, Hu RJ (2007) Recent and future climate change in northwest china. Clim Chang 80(3-4):379-393

Song MH, Zhou CP, Ouyang H (2004) Distributions of dominant tree species on the Tibetan Plateau under current and future climate scenarios. Mt Res Dev 24(2):166-173
Song MH, Zhou CP, Ouyang H (2005) Simulated distribution of vegetation types in response to climate change on the Tibetan Plateau. J Veg Sci 16(3):341-350

Su Z, Shi YF (2002) Response of monsoonal temperate glaciers to global warming since the Little Ice Age. Quat Int 97-8:123-131

Su HX, Sang WG, Wang YX, Ma KP (2007) Simulating Picea schrenkiana forest productivity under climatic changes and atmospheric $\mathrm{CO}_{2}$ increase in Tianshan Mountains, Xinjiang Autonomous Region, China. For Ecol Manage 246(2-3): 273-284

Tao FL, Yokozawa M, Hayashi Y, Lin ED (2005) A perspective on water resources in China: interactions between climate change and soil degradation. Clim Chang 68(1-2):169-197

UNFCCC (1992) The United Nations framework convention on climate change

Wang JXL, Gaffen DJ (2001) Late-twentieth-century climatology and trends of surface humidity and temperature in China. J Clim 14(13):2833-2845

Wang SW, Gong DY (2000) Enhancement of the warming trend in China. Geophys Res Lett 27(16):2581-2584

Wang FT, Zhao ZC (1995) Impact of climate change on natural vegetation in China and its implication for agriculture. J Biogeogr 22(4-5):657-664

Wang YQ, Zhou L (2005) Observed trends in extreme precipitation events in China during 1961-2001 and the associated changes in large-scale circulation. Geophys Res Lett 32:L09707

Wang SW, Gong DY, Zhu JH (2001) Twentieth-century climatic warming in China in the context of the Holocene. Holocene 11(3):313-321

Wang XM, Chen FH, Dong ZB (2006) The relative role of climatic and human factors in desertification in semiarid China. Glob Environ Chang 16(1):48-57

Wang YH, Zhou GS, Wang YH (2007) Modeling responses of the meadow steppe dominated by Leymus chinensis to climate change. Clim Chang 82(3-4):437-452

Wang Q, Zhao P, Ren H, Kakubari Y (2008a) Spatiotemporal dynamics of forest net primary production in China over the past two decades. Global Planet Chang 61(3-4):267-274

Wang XM, Chen F, Hasi E, Li JC (2008b) Desertification in China: an assessment. Earth Sci Rev 88(3-4):188-206

Weng ES, Zhou GS (2006) Modeling distribution changes of vegetation in China under future climate change. Environ Model Assess 11(1):45-58

Wu Q, Zheng XX, Xu H, Ying YF, Hou YS, Xie XC, Wang SX (2003) Relative sea-level rising and its control strategy in coastal regions of China in the 21st century. Sci China Ser D Earth Sci 46(1):74-83

Xiao JF, Moody A (2004) Trends in vegetation activity, their climatic correlates: China 1982 to 1998. Int J Remote Sens 25(24): $5669-5689$

Xiao X, Ojima DS, Parton WJ, Chen Z, Chen D (1995) Sensitivity of Inner Mongolia grasslands to climate change. J Biogeogr 22(4-5):643-648

Xu DY, Yan H (2001) A study of the impacts of climate change on the geographic distribution of Pinus koraiensis in China. Environ Int 27(2-3):201-205

Yan Z, Jones PD, Davies TD, Moberg A, Bergstrom H, Camuffo D, Cocheo C, Maugeri M, Demaree GR, Verhoeve T, Thoen E, Barriendos M, Rodriguez R, Martin-Vide J, Yang C (2002) Trends of extreme temperatures in Europe and China based on daily observations. Clim Chang 53(1-3):355-392

Yang DW, Li C, Hu HP, Lei ZD, Yang SX, Kusuda T, Koike T, Musiake K (2004a) Analysis of water resources variability in the Yellow River of China during the last half century using historical data. Water Resour Res 40(6) 
Yang MX, Wang SL, Yao TD, Gou XH, Lu AX, Guo XJ (2004b) Desertification and its relationship with permafrost degradation in Qinghai-Xizang (Tibet) plateau. Cold Reg Sci Technol 39(1):47-53

Yang X, Zhang K, Jia B, Ci L (2005) Desertification assessment in China: an overview. J Arid Environ 63(2):517-531

Yu M, Gao Q, Liu YH, Xu HM, Shi PJ (2002) Responses of vegetation structure and primary production of a forest transect in eastern China to global change. Global Ecol Biogeogr 11(3):223-236

Yu L, Cao MK, Li KR (2006) Climate-induced changes in the vegetation pattern of China in the 21 st century. Ecol Res 21(6):912-919

Yue TX, Liu JY, Jorgensen SE, Gao ZQ, Zhang SH, Deng XZ (2001) Changes of Holdridge life zone diversity in all of China over half a century. Ecol Modell 144(2-3):153-162

Yue TX, Fan ZM, Liu JY (2005) Changes of major terrestrial ecosystems in China since 1960. Global Planet Chang 48(4): 287-302

Yue TX, Fan ZM, Liu JY, Wei BX (2006) Scenarios of major terrestrial ecosystems in China. Ecol Modell 199(3):363-376

Yue TX, Fan ZM, Liu JY (2007) Scenarios of land cover in China. Global Planet Chang 55(4):317-342

Zhai PM, Pan XH (2003) Trends in temperature extremes during 1951-1999 in China. Geophys Res Lett 30(17):1913

Zhang YS, Li T, Wang B (2004) Decadal change of the spring snow depth over the Tibetan Plateau: the associated circulation and influence on the East Asian summer monsoon. J Clim 17(14): 2780-2793

Zhang YQ, Liu CM, Tang YH, Yang YH (2007) Trends in pan evaporation and reference and actual evapotranspiration across the Tibetan Plateau. J Geophys Res 112:D12110
Zhang Q, Xu CY, Zhang Z, Chen YD, Liu CL (2009) Spatial and temporal variability of precipitation over China, 1951-2005. Theor Appl Climatol 95(1-2):53-68

Zhao MS, Neilson RP, Yan XD, Dong WJ (2002) Modelling the vegetation of China under changing climate. Acta Geogr Sin 57:28-38

Zhao L, Ping CL, Yang DQ, Cheng GD, Ding YJ, Liu SY (2004) Changes of climate and seasonally frozen ground over the past 30 years in Qinghai-Xizang (Tibetan) Plateau, China. Global Planet Chang 43(1-2):19-31

Zhao SQ, Da LJ, Tang ZY, Fang HJ, Song K, Fang JY (2006) Ecological consequences of rapid urban expansion: Shanghai, China. Front Ecol Environ 4(7):341-346

Zheng DL, Wallin DO, Hao ZQ (1997) Rates and patterns of landscape change between 1972 and 1988 in the Changbai Mountain area of China and North Korea. Landsc Ecol 12(4):241-254

Zheng JY, Ge QS, Hao ZX (2002) Impacts of climate warming on plants phenophases in China for the last 40 years. Chin Sci Bull 47(21):1826-1831

Zheng Y, Xie Z, Jiang L, Shimizu H, Drake S (2006a) Changes in Holdridge Life Zone diversity in the Xinjiang Uygur Autonomous Region (XUAR) of China over the past 40 years. J Arid Environ 66(1):113-126

Zheng YR, Xie ZX, Robert C, Jiang LH, Shimizu H (2006b) Did climate drive ecosystem change and induce desertification in Otindag sandy land, China over the past 40 years? J Arid Environ 64(3):523-541

Zhu WQ, Pan YZ, Yang XQ, Song GB (2007) Comprehensive analysis of the impact of climatic changes on Chinese terrestrial net primary productivity. Chin Sci Bull 52(23):3253-3260

Zou XK, Zhai PM, Zhang Q (2005) Variations in droughts over China: 1951-2003. Geophys Res Lett 32:L04707 